Dewanckele J., Boone, M.A., De Kock, T., De Boever, W., Brabant, L., Boone, M.N., Fronteau, G., Van Hoorebeke, L., Jacobs, P., Cnudde, V. 2013. Holistic approach of pre-existing flaws on the durability of two limestones. Science of The Total Environment. 447. p.403-414. http://dx.doi.org/10.1016/j.scitotenv.2012.12.094

\title{
Holistic approach of pre-existing flaws on the decay of two limestones
}

J. Dewanckele ${ }^{\text {a, }}$ M.A. Boone ${ }^{\text {a }}$, T. De Kock ${ }^{\text {a }}$, W. De Boever ${ }^{\text {a }}$, L. Brabant ${ }^{\text {b }}$, M.N. Boone ${ }^{\text {b }}$, G. Fronteau ${ }^{\text {c }}$, J. Dils $^{\text {d }}$, L. Van Hoorebeke ${ }^{\text {b }, ~ P . ~ J a c o b s ~}{ }^{\text {a }}$, V. Cnudde ${ }^{\text {a }}$

${ }^{a}$ Department of Geology and Soil Science - UGCT, Ghent University, Krijgslaan 281 S8, B-9000, Ghent, Belgium

${ }^{\mathrm{b}}$ Department of Physics and Astronomy — UGCT, Ghent University, Proeftuinstraat 86, B-9000 Ghent, Belgium

${ }^{c}$ University of Reims Champagne-Ardenne (URCA), GEGENAA, EA3795, Reims, France

${ }^{\mathrm{d}}$ Department of Structural engineering, Ghent University, Technologiepark Zwijnaarde 904, 9052, Zwijnaarde, Belgium

\section{Highlights:}

- Understanding the microfacies influence on the weathering behavior of limestones.

- A combination of X-ray CT, SEM and thin section microscopy was used.

- Gypsum crystallization depends on the pore size distribution and reactive surface.

- Orbitolites complanatus are pre-existing flaws in the Noyant stone.

\section{Keywords:}

Gypsum crystallization, Time lapse X-ray CT, Natural building stone, Freeze-thaw weathering

\section{Abstract:}

This study aims to understand the influence of the microfacies and the determination of pre-existing flaws on the weathering behavior of two types of limestones. Therefore, both Lede and Noyant limestones were independently weathered by strong acid tests and freeze-thaw cycles. In order to characterize the weathering patterns inside the stones, a combination of high resolution X-ray CT, SEM-EDS and thin section microscopy was used. The advantage of high resolution X-ray CT is its non-destructive character and the obtained 3D structural information. By using this technique, a time-lapse sequence of the weathering patterns was obtained for both gypsum crust formation as well as crack formation due to freezing and thawing. This way, a clear link could be made with the initial non-weathered state. Thin section microscopy and SEM-EDS provided additional chemical information. The focus of this study lies in the processes that occur in the bioclast fragments in the stone and the influence of the surrounding cement or matrix. The results show that weathering patterns vary for both limestones although the causes of weathering were similar. In case of the Noyant stone, the weathering by crystallizing gypsum was mainly restricted to the microporous matrix of the stone, while in case of the Lede stone, several foraminifera and shell fragments were preferentially recrystallized. In general, the underlying microstructure determines the weathering pattern of the stone.

\section{Introduction}

Weathering of natural building stones and dimension stones is a well discussed topic in literature (Torok et al., 2011; Camuffo, 1995; Dolske, 1995; Lopez-Arce et al., 2010; Ortiz et al., 2010; Ruedrich et al., 2011; Thomachot-Schneider et al., 2008). A central issue in those weathering processes is the development of crusts on limestones due to polluted, urban environment (Cnudde et al., 2009; Leysen et al., 1990; Matovic et al., 2012; Sanjurjo et al., 2009, 2011; Torok and Rozgonyi, 2004; Zappia et al., 1998). Generally, crusts are formed due to the interaction of external factors (rain, dust, particulate matter, etc.) with the surface and internal material of the stone. Due to dissolution, recrystallization and deposition processes, a new superficial layer can be formed. On limestone, gypsum crusts are the most common superficial transformations. The main aggressor in the formation of gypsum crusts is sulfur dioxide gas $\left(\mathrm{SO}_{2}\right)$. This gas is highly soluble in water and reacts, in combination with water, with the calcium carbonate of the limestone resulting in recrystallizations of calcium carbonate and newly formed gypsum crystals (Charola et al., 2007). In case of sheltered parts of a façade, the accumulation will continue due to condense on the wet surface and the lack of removal by direct impact of rain (Montana et al., 2008; Siegesmund et al., 2007). 
Dewanckele J., Boone, M.A., De Kock, T., De Boever, W., Brabant, L., Boone, M.N., Fronteau, G., Van Hoorebeke, L., Jacobs, P., Cnudde, V. 2013. Holistic approach of pre-existing flaws on the durability of two limestones. Science of The Total Environment. 447. p.403-414. http://dx.doi.org/10.1016/j.scitotenv.2012.12.094

Different techniques have been used to characterize natural building stones and their weathering patterns ranging from optical inspection and optical microscopy (Bai et al., 2003; Kapsalas et al., 2007) to SEM, infrared and X-ray diffraction (Maravelaki-Kalaitzaki and Biscontin, 1999; Montana et al., 2008; Thomachot-Schneider et al., 2008; Thomachot and Jeannette, 2004). Recently, new techniques like high resolution X-ray computed tomography (HRXCT) are being addressed in the assessments of weathering of natural building materials (Bugani et al., 2008; Cnudde et al., 2004; De Graef et al., 2005; De Muynck et al., 2011; Rozenbaum, 2011). However, the quantification of the weathering processes is often indirect and in most cases only the failed situation is taken into account. Destructive techniques such as thin section petrography, SEM and mercury intrusion porosimetry (MIP) are mostly applied to obtain pore scale information on weathering processes. In order to control the parameters and accelerate the processes of weathering such as gypsum crust formation or freeze-thaw damage, several standard induced weathering tests exist. The accumulation of gypsum for example has been broadly characterized by induced weathering tests (NBN EN 12371, 2010; NBN EN 13919, 2003). In a previous article (Dewanckele et al., 2012), quantification of gypsum crust formation on Lede stone was reported, and an overview was presented of the characterization of the changing pore structure in three dimensions in function of weathering time. The research focused on the quantification of altered pore structures using HRXCT rather than on the mechanisms of crust formation itself. Recently, the resolution and quality of X-ray CT images increased significantly and allowed quantification of complex pore structures. However, for the 3D characterization of weathering processes on pore scale inside natural building stones, both 3D structural and chemical quantifications are crucial, especially when recrystallization of gypsum or other salts is present. When frost action is taken into account, no chemical information is needed because most of the damaging processes are mechanical (crack-formation, clipping, detachment, etc.) (Bost and Dubied, 2007; Nicholson and Nicholson, 2000).

This paper has a different approach to the complex weathering processes inside limestones. It focuses on the micromorphology of two geological-time equivalent natural building stones, the Lede stone and the Noyant limestone and the susceptibility of bioclast as pre-existing flaws to gypsum formation and freeze- thaw cycles. Lede stone and Noyant stone are both limestones containing a significant amount of bioclast, especially foraminifera. Foraminifera are small, predominantly single-celled marine organisms that build chambered shells (Bathurst, 1971; Scholle and UlmerScholle, 2003) made up of high- or low-magnesium calcite. They range from a few tens of microns in diameter to tens of millimeters across. Consequently, these specific bioclasts are important to take into account into the overall weathering process of natural building stones. In order to predict weathering phenomena and rates, first, the role of the microstructure has to be considered. Most literatures provide general weathering process rates but are less focussing on specific features of the stone. On the other hand Fronteau et al. (2010b), already illustrated the relationship between building stone microfacies and morphology of the lower layer of sulfated encrusting.

In this study, we describe a HRXCT research, combined with thin section microscopy and SEM-EDS, of weathering forms in foraminifera inside two different limestone facies due to freeze- thaw and gypsum crystallization. The approach of combining these techniques allowed to obtain a time lapse visualization of specific disintegration processes and to compare the observed weathering patterns in relation with the microstructure of the rock.

\begin{tabular}{|c|c|c|c|c|c|c|c|c|}
\hline $\begin{array}{l}\text { Stone } \\
\text { name }\end{array}$ & Rock type & $\begin{array}{l}\text { Porosity } \\
(\%)\end{array}$ & $\begin{array}{l}\text { Specific total pore } \\
\text { surface area } \\
\left(\mathrm{mm}^{2} / \mathrm{g}\right)\end{array}$ & $\begin{array}{l}\text { Apparent } \\
\text { volumetric } \\
\text { mass }\left(\mathrm{kg} / \mathrm{m}^{3}\right)\end{array}$ & Mineralogy & Cement/matrix & Components & $\mathrm{CaCO}_{3} \%$ \\
\hline Lede & $\begin{array}{l}\text { Calcarenite/ } \\
\text { grainstone }\end{array}$ & $5-10 \%$ & 1.15 & $2559.8 \pm 30.8$ & $\begin{array}{l}\text { Quartz, glauconite, } \\
\text { pyrite, zircon, calcite }\end{array}$ & $\begin{array}{l}\text { Micritic-microsparitic } \\
\text { cement }\end{array}$ & $\begin{array}{l}\text { Echinoderms, bivalves, gastropods, Foraminifera } \\
\text { (Quinqueloculina and Nummulites variolarius) }\end{array}$ & $30-60 \%$ \\
\hline Noyant & $\begin{array}{l}\text { Biomicrite/ } \\
\text { wackestone }\end{array}$ & $40-50 \%$ & 3.65 & $1714.7 \pm 10.0$ & $\begin{array}{l}\text { Quartz, iron oxides, } \\
\text { calcite }\end{array}$ & Micritic matrix & $\begin{array}{l}\text { Foarminifera (Quinqueloculina, Triloculina, } \\
\text { Orbitolites complanatus), shell fragments }\end{array}$ & $90-95 \%$ \\
\hline
\end{tabular}

\section{Methods and materials}

2.1. Materials

2.1.1. Lede stone 
Dewanckele J., Boone, M.A., De Kock, T., De Boever, W., Brabant, L., Boone, M.N., Fronteau, G., Van Hoorebeke, L., Jacobs, P., Cnudde, V. 2013. Holistic approach of pre-existing flaws on the durability of two limestones. Science of The Total Environment. 447. p.403-414. http://dx.doi.org/10.1016/j.scitotenv.2012.12.094

Lede (or Balegem) stone is a fossil-rich, sandy limestone from the Lede Formation (middle Eocene) in Belgium (Fobe, 1990). This glauconitic stone is a very important historical natural building stone in Flanders and The Netherlands and has been used since Roman times. An overview of the most important features of the rock is shown in Table 1. Besides calcitic cement and glauconite, 40 up to $70 \%$ of quartz grains can be found, as well as small amounts of pyrite and some fine distributed dense minerals. The microscopic texture can be described as being without structure towards a laminated packstone and a bioclastic packstone or grainstone (Dusar et al., 2009). The stone has a bimodal grain size distribution with the smallest grains having a length of $83.32 \pm 26.34 \mu \mathrm{m}$ and the biggest group $386.67 \pm 127.02 \mu \mathrm{m}$. The porosity of the stone is very heterogeneous (5-10\%) due to a varying macroporosity of dissolved fossil fragments. The cumulative pore volume of the Lede stone is shown in Fig. 1 and is measured with mercury intrusion porosimetry (MIP). The specific pore area surface shown in Table 1 is also derived from MIP. The fossil fragments in the Lede stone are fragments of echinoderms, such as sea urchins, bivalves, gastropods, Ditrupa strangulata and foraminifera. The latter belong mostly to the subgroup Miliolina and are fragments or complete parts of Quinqueloculina. The Miliolina in the Lede stone have a length of $208.35 \pm 82.50 \mu \mathrm{m}$. They appear dark to amber-colored in transmitted light and have a porcelaneous wall with an inner and outer surface layer. Porcelaneous foraminifera walls are imperforate, with a random orientation of the crystallites, in optical microscopy, they are dark with fine-grained appearance (Bathurst, 1971; Scholle and Ulmer-Scholle, 2003). Furthermore, Nummulites variolarius (subgroup Rotaliina) are regularly found in the stone (length of $1016.13 \pm 78.92 \mu \mathrm{m}$ ). This type of foraminifera is diskshaped and sometimes may grow to sizes of a centimeter in diameter. The hyaline walls of these foraminifera are sometimes coarsely perforated and composed of radial calcite. The individual crystals are orientated with their long axes at right angles to the wall (Scholle and Ulmer-Scholle, 2003). The apparent volumetric mass of the stone amounts $2559.8 \pm 30.8 \mathrm{~kg} / \mathrm{m}^{3}$ (De Kock, 2009). In an urban environment the stone is vulnerable to severe weathering. In most cases, the weathering results in the formation of gypsum crusts, combined with a significant discoloration (Fobe, 1990). Those weathering crusts are related to sulfation process and are linked to the mineral composition of the stone (calcium carbonate cement). In well sheltered areas of a building façade, the gypsum crust can accumulate to a thickness of several centimeters, while in more exposed areas, the crust reaches only a few millimeters of thickness. Because of those processes, severe esthetical and structural problems may occur. In combination with freeze-thaw cycles or not, those crusts can rapidly peel off, and expose the weaker underlying structure to the urban environment.

\subsubsection{Noyant}

Noyant limestone, from 'Roche fine' type, is frequently used in France but is not a commonly used historical building stone in Belgium. However, this stone is available in Belgium as restoration material or for new construction of new products. The Noyant limestone is found in the Calcaire grossier formation (France; Lutetian, middle Eocene) and is thus a geological-time equivalent stone of the Lede stone (Fronteau et al., 2010a). The different extraction zones are situated in the surroundings of Soissons and Septmonts. This very porous stone (up to 50\% porosity) ranges over white-beige to yellow-beige in color. Characteristics of the stone are shown in Table 1. The porosity is mainly composed of intramatrix micropores, but dissolution of larger shell fragments results in macroscopic moldic pores enlarged up to several centimeters. Fig. 1 shows the cumulative pore volume for the Noyant stone. Like in the case of the Lede stone, the Noyant also contains foraminifera of the Miliolina subgroup (Quinqueloculina, Triloculina) with a length of $453.89 \pm 115.23 \mu \mathrm{m}$. Orbitolites complanatus, another porcelaneous foraminifera are often present in the stone and they can have a length of several millimeter. Noyant appears to be an almost pure limestone with a micritic matrix. Furthermore, some dispersed, subangular quartz grains (length of $66.62 \pm 35.95 \mu \mathrm{m}$ ) are present. The limestone can be classified as a biomicrite according to Folk. The apparent mass of the stone amounts $1714.7 \pm 10.0 \mathrm{~kg} / \mathrm{m}^{3}$ (De Kock, 2009). 
Dewanckele J., Boone, M.A., De Kock, T., De Boever, W., Brabant, L., Boone, M.N., Fronteau, G., Van Hoorebeke, L., Jacobs, P., Cnudde, V. 2013. Holistic approach of pre-existing flaws on the durability of two limestones. Science of The Total Environment. 447. p.403-414. http://dx.doi.org/10.1016/j.scitotenv.2012.12.094

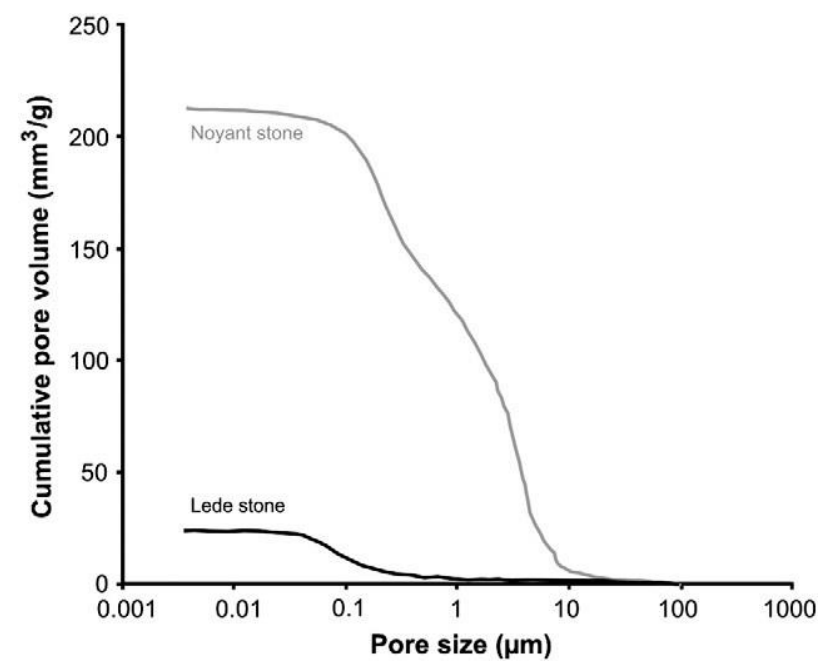

Fig. 1. Pore size distribution of the Lede and Noyant stones.

\subsection{Induced weathering test}

\subsubsection{Strong acid test}

In this study, sulfated encrustations were obtained on both Lede and Noyant stones in laboratory after an induced strong acid test. The reader is referred to Dewanckele et al. (2012) for further details. Basically, the samples were put in an acid environment according to the European Standard NBN EN 13919 (2003) for 21 days. At the bottom of the recipient, a mixture of $500 \pm 10 \mathrm{ml} \mathrm{H}_{2} \mathrm{SO}_{3}$ and $150 \pm 10 \mathrm{ml}$ de-mineralized $\mathrm{H}_{2} \mathrm{O}$ was added. The interaction of the limestones to this environment causes sulfated crust to be formed. Before starting the test, the samples were impregnated by water at atmospheric pressure and the relative humidity inside the box amounted to more than $90 \%$ relative humidity. Four $5 \times 5 \times 5 \mathrm{~cm}$ cubes of Lede and Noyant underwent the acid test for the preparation of thin sections and 1 cylindrical core of $1.6 \mathrm{~mm}$ of Noyant and Lede was used for the HRXCT and SEM-EDS measurements. For the Lede stone, besides laboratory induced samples also naturally weathered samples were used for the observations with thin section microscopy.

\subsubsection{Freeze-thaw cycles}

Initially, the frost resistance test was performed according to the Belgian norm (NBN B17-001, 1999) on 6 cubic samples of $5 \times 5 \times 5 \mathrm{~cm}$ samples of both Lede and Noyant limestones. The samples were first saturated with water. Afterwards, the samples were placed in a container, filled with granulates in such a way that the surfaces of the samples were still visible and subsequently water at $15^{\circ} \mathrm{C}$ was added. Finally, the samples were subjected to 25 frost cycles, 10 cycles with a maximum temperature drop to $-15^{\circ} \mathrm{C}$ and 15 cycles with a temperature drop to $-5^{\circ} \mathrm{C}$. Those temperatures were kept constant for a period of 5 to $6 \mathrm{~h}$. In between the cycles, the temperature was raised again by adding water of $15{ }^{\circ} \mathrm{C}$. However, to see the microscopic weathering processes, which includes weathering of bioclasts, the above described method was not ideally suited. The prime information obtained by this kind of test is mainly indirect (visual inspection, weighting and sound speed propagation), which makes it very difficult to investigate pore scaled changes by freezing and thawing. In order to truly obtain a pore scale visualization and quantification through time, HRXCT scanning (explained in Section 2.3) was performed on 2 sets of new samples of Noyant stone. In order to visualize and quantify the different stages of frost weathering the setup described above was downscaled and redesigned to fit the $\mathrm{X}$ ray CT setup. Seven cylinders of $9 \mathrm{~mm}$ (20 mm height) and one of $1.6 \mathrm{~mm}$ (3 mm height) were drilled in a fresh block of Noyant limestone. The samples were scanned before and after each freeze-thaw cycle (Fig. 2). In total, for the $9 \mathrm{~mm}$ diameter samples 11 cycles were performed and for the $1.6 \mathrm{~mm}$ samples only 4 cycles were completed. All samples were placed in a plastic tube, saturated with water (under atmospheric conditions) and retained in a freezing unit $\left(-15 \pm 1.5^{\circ} \mathrm{C}\right)$ for a period of $5 \mathrm{~h}$. Based on the total weathering (pulverization) of the $5 \times 5 \times 5 \mathrm{~cm}$ Noyant samples and no visible 
Dewanckele J., Boone, M.A., De Kock, T., De Boever, W., Brabant, L., Boone, M.N., Fronteau, G., Van Hoorebeke, L., Jacobs, P., Cnudde, V. 2013. Holistic approach of pre-existing flaws on the durability of two limestones. Science of The Total Environment. 447. p.403-414. http://dx.doi.org/10.1016/j.scitotenv.2012.12.094

weathering of the Lede stone, only the Noyant stone was selected to drill subsamples for the adapted weathering test with HRXCT.

\subsection{High resolution $\mathrm{X}$-ray $\mathrm{CT}$ and image analysis}

High resolution X-ray CT (HRXCT) reveals the internal structure of objects in three dimensions. Several publications already explained the basic principles of this technique and provided a good overview of some geological applications (Cnudde et al., 2006; Duliu, 1999; Ketcham and Carlson, 2001). Basically, an X-ray CT system consists of an X-ray source, detector and rotational stage. The sample is placed on the stage, between the source and the detector. By rotating the sample over $360^{\circ}$, several radiographs are obtained. Those radiographs are based on the X-ray attenuation of the Xray through the object and mainly depend on the chemical composition and density of the object. The experiments were performed at the Centre for X-ray Tomography at Ghent University, Belgium (UGCT; www.ugct.ugent.be) (Masschaele et al., 2007; Vlassenbroeck et al., 2007b). A filtered back-projection algorithm was used to reconstruct the normalized radiographs with the software Octopus, developed in-house (Dierick et al., 2004) and resulted in 16-bit gray scale images. To obtain a resolution of $2.5 \mu \mathrm{m}$, the scanned cylinder had only a diameter of $1.6 \mathrm{~mm}$. For each projection 6 frames were taken with an exposure time of $500 \mathrm{~ms}$. A voltage of $80 \mathrm{kV}$ was installed and the tube current was around $32 \mu \mathrm{A}$. An aluminum filter was used to reduce beam hardening. The exact position of the scan was saved on the computer and used for the other scans on the same sample.

For this study, different series of scans were compared. One series of scans was taken before gypsum crust formation and one after 21 days of weathering. Another series of scans was performed on the Noyant limestone during freezing and thawing. In order to do so, the positioning, the resolution, the reconstruction and beam hardening correction were the same for both scans. The reconstruction of the sample resulted in gray scale images on which the different minerals and components were visible due to a difference in their gray value which depended on their X-ray attenuation. Quartz attenuates the X-rays less than calcite and thus the difference between both is clearly visible in the slices, resulting in dark gray quartz grains and a lighter calcium carbonate cement. The problem arises when gypsum has to be separated from calcium carbonate. The attenuation coefficient of both minerals is almost the same, so it is nearly impossible to threshold both. In order to obtain a significant 3D distribution of newly formed gypsum crystals and an exact location of the minerals, digital image subtracting had to be performed on the two volumes. Because of the necessity to remove the samples from the scanner to put them in an acid environment, a small shift of some voxels was visible. Although all scan and reconstruction parameters were kept constant for both scans, the two data sets (before and after weathering) had to be registered in 3D by using the registration module of VGStudio® MAX 2.1 from Volume Graphics. A region of interest was chosen inside both samples and afterwards registered with the software from Volume Graphics. A differential volume was obtained by subtracting the initial volume from the registered weathered volume with ImageJ. In this way, the differential volume revealed only the structural changes that occurred in between the two scans. The formation of new pores, due to the dissolution of calcium carbonate, and the development of microcracks, on the border of the quartz grains, resulted in a very low gray value, while the location of the gypsum crystallization resulted in a higher gray value. The non-changing structures obtained a mid-tone gray value. The replacement of calcium carbonate by gypsum cannot be visualized because of similar attenuations. Because of that, in this study no quantitative analyses on the amount of gypsum formed inside the stone could be done, because the results obtained would have been underestimated. The new subtracted slices were afterwards used to threshold in Morpho+ (Brabant et al., 2011; Vlassenbroeck et al., 2007a). Although,before thresholding the gypsum crystals, a bilateral filter was applied to remove random noise from the image.

\subsection{Petrographical microscope and SEM-EDS}

Both petrographic microscopy and scanning electron microscopy with an energy-dispersive X-ray detector (SEM/EDS) were used to visualize and analyze the changes that occurred inside Lede and Noyant stones after gypsum crystallization. A Zeiss Axio Scope A1 polarization microscope with transmitted light was used for the petrographic study and fluorescent analysis of both laboratory induced weathered samples as well as naturally weathered samples. In 
Dewanckele J., Boone, M.A., De Kock, T., De Boever, W., Brabant, L., Boone, M.N., Fronteau, G., Van Hoorebeke, L., Jacobs, P., Cnudde, V. 2013. Holistic approach of pre-existing flaws on the durability of two limestones. Science of The Total Environment. 447. p.403-414. http://dx.doi.org/10.1016/j.scitotenv.2012.12.094

addition, some thin sections were impregnated with fluorescent dye in order to reveal the pore structure of the stone especially inside the bioclasts.

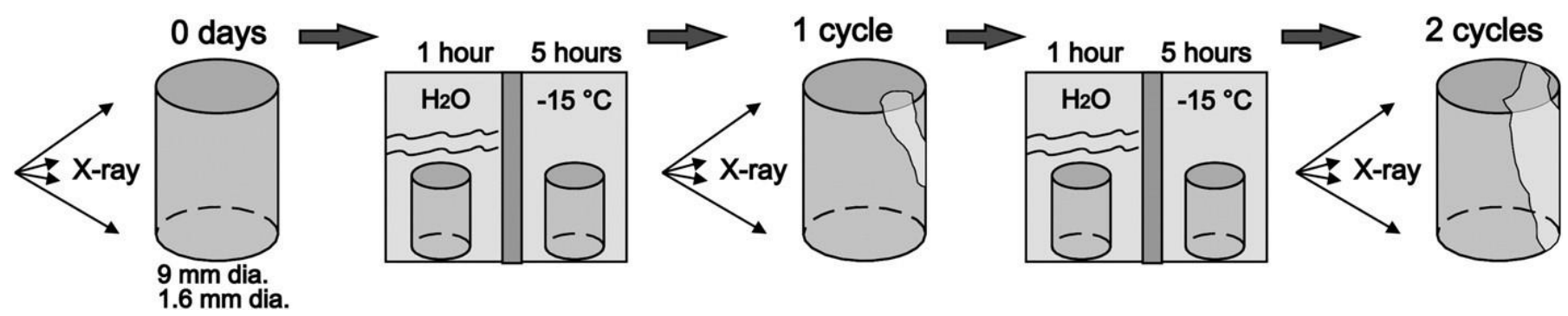

Fig. 2. Overview of the set-up of the freeze-thaw test with X-ray CT for the Noyant sample.

Also, the impregnation held the stone together, preventing the gypsum to fall apart during the preparation processes. For the SEM and EDS analysis, a JSM-5310LV system was used. By embedding, cutting and polishing, internal surfaces of the cylindrical cores were obtained and could be linked with the slices obtained by HRXCT. A magnification of 350x was installed for the SEM visualizations with $30 \mathrm{kV}$ and $65 \mu \mathrm{A}$. A spot size of 14 was chosen with a working distance of 29. For the EDX mappings, 70 frames were taken with $15 \mathrm{~s}$ for each measurement. The sample was first coated with carbon. The final mappings had a resolution of 256×192 pixels. All mappings were afterwards recalled and repositioned with Photoshop on top of an overview SEM image (150× magnification).

\section{Results}

3.1. Gypsum crystallization

3.1.1. Lede stone

3.1.1.1. Petrographic microscopy.

For the Lede stone, both naturally weathered and induced weathered samples were observed with thin sections. On both the laboratory treated as well as on the naturally weathered samples, a gypsum crust is visible. It sometimes exceeded more than $200 \mu \mathrm{m}$ and was mainly composed of newly formed gypsum crystals, recrystallized calcium carbonate and detached quartz and glauconite grains. As explained, the recrystallization phenomenon is studied inside the bioclast fragments. In Fig. 3, a non-weathered foraminifer (Miliolina) is demonstrated in both transmitted light and fluorescence image mode. On the latter all the pores are shown in green. As can be seen on the figure, in plane polarized light and crossed polarized light, the dark-amber-colored unpunctuated wall structures demonstrate random orientated calcite microcrystals. But, the wall structures of the Miliolids in the Lede stone are highly microporous, resulting in a bright green color in fluorescence mode. Some microstructural weathering processes inside the bioclasts are visible in Fig. 4. Thin sections shown in Fig. 4 are samples from the Sint-Salvator church in Wieze (Belgium), from the spire, sheltered from direct rain. Fig. 4A and B shows foraminifera (Miliolina), just below a naturally formed gypsum crust (Gy). For both cases, plane polarized and crossed polarized light figures are exposed. Both foraminifera are covered with a thick $( \pm 200 \mu \mathrm{m})$ gypsum crust and are only partially integrated in the crust. In the top row (Fig. 4A) a preferential infilling is visible of the wall of the fossil test by gypsum (arrows).

Some parts are completely filled with secondary gypsum and are visible in crossed polarized light by a gray (first order) interference color. The same observations can be seen on the bottom row (Fig. 4B). In this figure, the microsparitic cement inside the microfossil chambers is more resistant than the surrounding wall structure. The wall structure is completely recrystallized and integrated in the crust. Even parts of the wall below the crust are weathered. All foraminifera (Miliolina) near the surface of the sample are observed to be partially and even completely filled with gypsum. This phenomenon is also visible in the bottom row (C) in Fig. 4. The foraminifer, impregnated with fluorescent resin shows the decrease of porosity inside the wall structure. Only some central parts of the animal test are still colored bright green, thus showing some prestine microporosity. The outer parts of the fossil (arrow) are filled with gypsum, 
Dewanckele J., Boone, M.A., De Kock, T., De Boever, W., Brabant, L., Boone, M.N., Fronteau, G., Van Hoorebeke, L., Jacobs, P., Cnudde, V. 2013. Holistic approach of pre-existing flaws on the durability of two limestones. Science of The Total Environment. 447. p.403-414. http://dx.doi.org/10.1016/j.scitotenv.2012.12.094

resulting in a decrease of porosity. In general, the Miliolid fragments in the Lede stone tend to weather more rapidly than the surrounding calcite cement, by recrystallizing the wall structures. The secondary formed gypsum crystals almost filled the whole structure of the fossil, situated up to some millimeters below the sulfated encrustation.
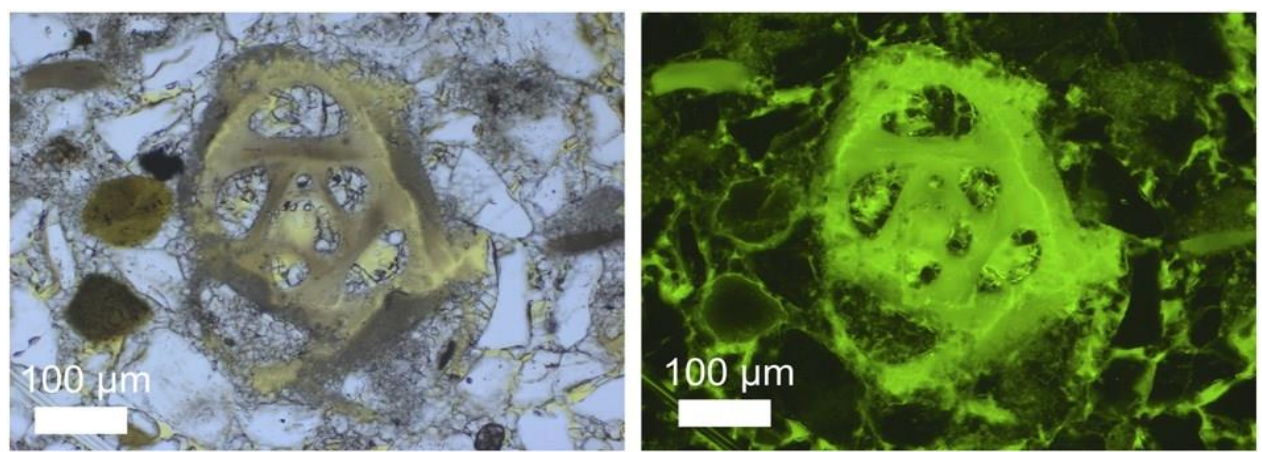

Fig. 3. Thin section overview of pore space in the Miliolina fragments inside a fresh Lede stone. The thin section was impregnated with a fluorescent dye, making the highly micro- and nanoporous wall structure of the foraminifera visible (green). (For interpretation of the references to color in this figure legend, the reader is referred to the web version of this article.)
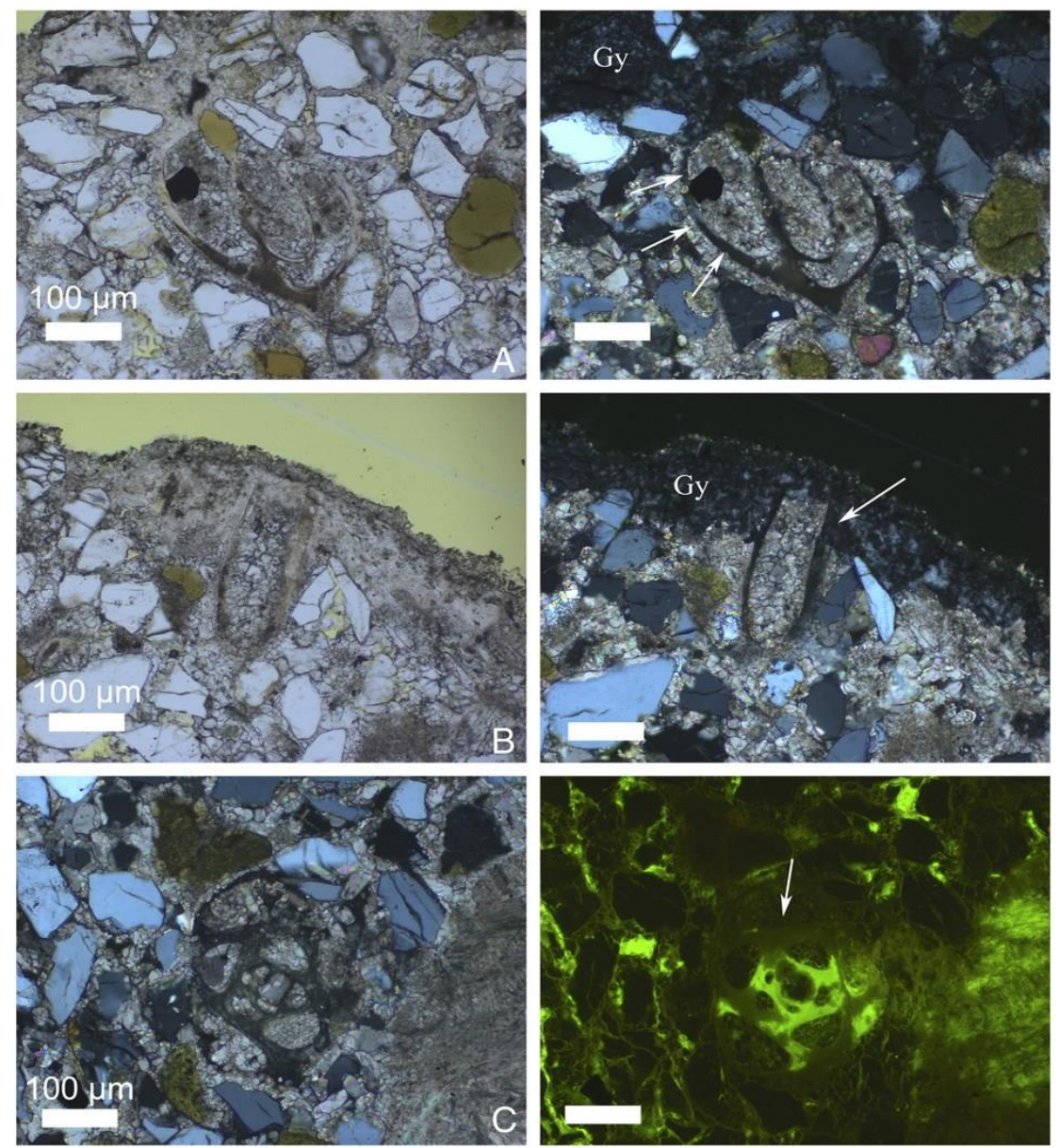

Fig. 4. Thin section overview of urban environment weathering patterns of Miliolina fragments in the Lede stone, just below a gypsum crust (Gy; gray in crossed polarized light). In the top row (A) the infilling of the wall structures of the animal test is visible (arrow). The middle row (B) clearly demonstrates the differential weathering; the calcite cement inside the chambers of the animal test is more resistant than the wall structure. Thanks to the fluorescent resin, the bottom row shows the decrease in porosity due to gypsum crystallization. (For interpretation of the references to color in the text with the citation of this figure, the reader is referred to the web version of this article.) 
Dewanckele J., Boone, M.A., De Kock, T., De Boever, W., Brabant, L., Boone, M.N., Fronteau, G., Van Hoorebeke, L., Jacobs, P., Cnudde, V. 2013. Holistic approach of pre-existing flaws on the durability of two limestones. Science of The Total Environment. 447. p.403-414. http://dx.doi.org/10.1016/j.scitotenv.2012.12.094

A complete different weathering pattern is found when looking at the foraminifera N. variolarius. Those fossils are part of the subgroup Rotaliina and have hyaline calcareous wall structures. Thin sections colored with fluorescent epodye show almost no microporosity in the wall structure of the non-weathered fossil test. An overview of some weathering patterns of the N. variolarius in the Lede stone is illustrated in Fig. 5. The first row (A) only shows a fragment of the fossil, situated in a weathered zone of the stone, some millimeters below the actual external gypsum crust (sample from the Sint-Salvator church in Wieze (Belgium), from the spire, sheltered from direct rain). Big crack structures are visible in the fluorescent images and some weaker parts of the fossil are dissolved (arrow). The dissolved, porous areas are located in between the lamellar zones of the fossil. However, most of the fossil fragments show no indications of dissolution due to the increased acid urban environment. Fragments of the N. variolarius partially and fully incorporated in the gypsum crust are shown in the middle (Fig. 5B) and the bottom row (Fig. 5C) (sample from a black crust on a sheltered part of the wall of the Sint-Anna church in Ghent, Belgium). In the middle row, a part of a N. variolarius is shown, after laboratory induced weathering. An external gypsum crust (Gy) is visible. The wall structures of the animal test are less prone to weathering than the zones in between and the surrounding cement. The arrows indicate the wall structures, standing more in relief. Occasionally, the calcium carbonate is dissolved and replaced by gypsum only in the outer layer of the fossil and gradually follows the lamella border of the wall structure, resulting in a lateral weathering pattern. The inner part of the fossil is still intact, while close to the fossil, quartz grains are already entirely incorporated in to the gypsum crust. On the bottom row (Fig. 5C), all the cement between the quartz grains is recrystallized and only a central part of the fossil remained in its pristine stage. The thin sections show that $\mathrm{N}$. variolarius is thus more resistant to recrystallization in an urban environment than the surrounding calcitic cement.

3.1.1.2. High resolution X-ray CT. The great advantage of X-ray computed tomography for the study of weathering processes in natural building stones is its non-destructive character. By inducing weathering and scanning the sample before, during and after weathering, the same structural information can be obtained. As previously observed and quantified (Dewanckele et al., 2012), a thick external gypsum crust was clearly visible after induced weathering tests on the Lede stone. The porosity increase after the experiment was due to the dissolution of calcium carbonate just below the crust. Coalescence of pore structures resulted in an increase of the open pore structure after 21 days of weathering. The weathering of the stone was quantified based on the changes in porosity and pore structure. In this study, a differential volume was thresholded to determine the location of the recrystallizations inside the stone. The registration of both volumes was relatively simple, because no displacement of the quartz grains occurred inside the sample. It is observed that the crystallization of gypsum inside the stone was mainly concentrated on fossil fragments. Fig. 6 shows a reconstructed slice before weathering (A), the same image after weathering (B) and a differential image (C) by subtracting both images from one another. Because of the subtraction the non-changed structures are removed from the image and thus only the structural changes become visible. The zones colored black in the figure (C) are newly formed pore structure because of the dissolution and removal of calcium carbonate. The zones in white are the areas where gypsum and/or recrystallized calcium carbonate are formed where, before the experiment, a porous zone was present. The arrows in the figure indicate the parts of foraminifera (Miliolina) and a moldic macropore structure (dissolved shell fragment) in white, thus filled with gypsum. Also, the external gypsum layer, covering the whole surface of the cylindrical core, is visible. By thresholding the white areas on the differential image, the gypsum could be virtually segmented. An overview of the segmented gypsum phase is shown in red in Fig. 7. The figure demonstrates a 2D reconstructed slice before and after the weathering test. In the central region, a Nummulites (Num) is visible and as can be seen after the weathering test, no structural changes occurred inside. Only the outer part of the partially dissolved shell fragment (DS), a large fragment of a Miliolina and some microporous zones inside the cement were recrystallized. By rendering the thresholded images in VGStudio ${ }^{\circledR}$, a full 3D image of the location of gypsum crystallization inside the Lede stone was obtained. The 3D image, as shown in Fig. 8, indicates in red the locations with gypsum neoformation. The surface of the sample was artificially made semi-transparent. As can be seen in the figure (in red), the zones of 
Dewanckele J., Boone, M.A., De Kock, T., De Boever, W., Brabant, L., Boone, M.N., Fronteau, G., Van Hoorebeke, L., Jacobs, P., Cnudde, V. 2013. Holistic approach of pre-existing flaws on the durability of two limestones. Science of The Total Environment. 447. p.403-414. http://dx.doi.org/10.1016/j.scitotenv.2012.12.094

recrystallization inside the stone are mainly restricted to the Milliolid fragments, which can be recognized in 3D by the preferential gypsum recrystallization, and to the dissolved shell fragment.
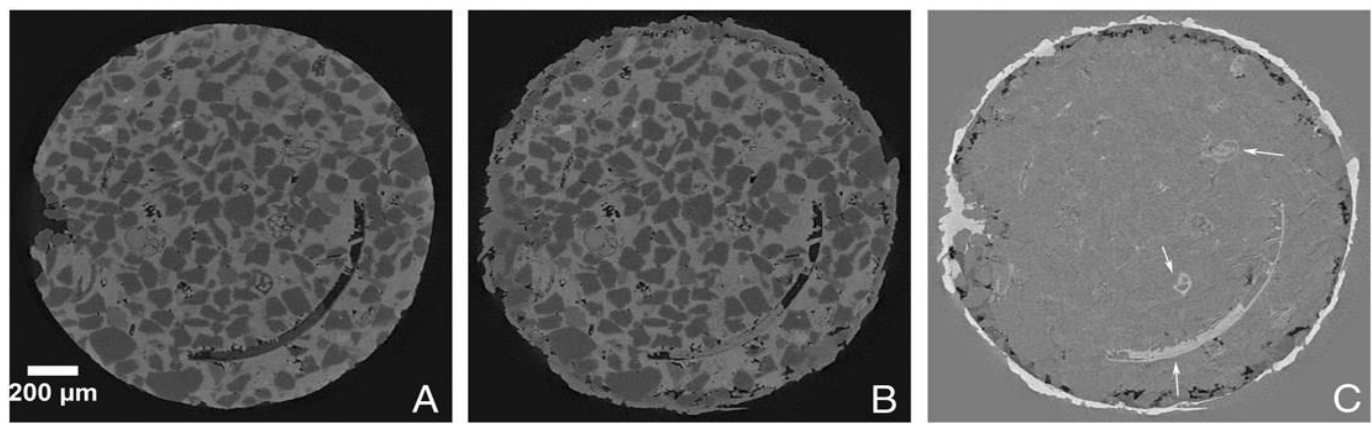

Fig. 6. Reconstructed slice of the Lede stone before (A) and after weathering (B). The differential image (C) is obtained by subtracting A from B. Zones in white are the gypsum crystallizations (arrows). Diameter of the sample is $1.6 \mathrm{~mm}$ and the resolution is $2.5 \mu \mathrm{m}$.
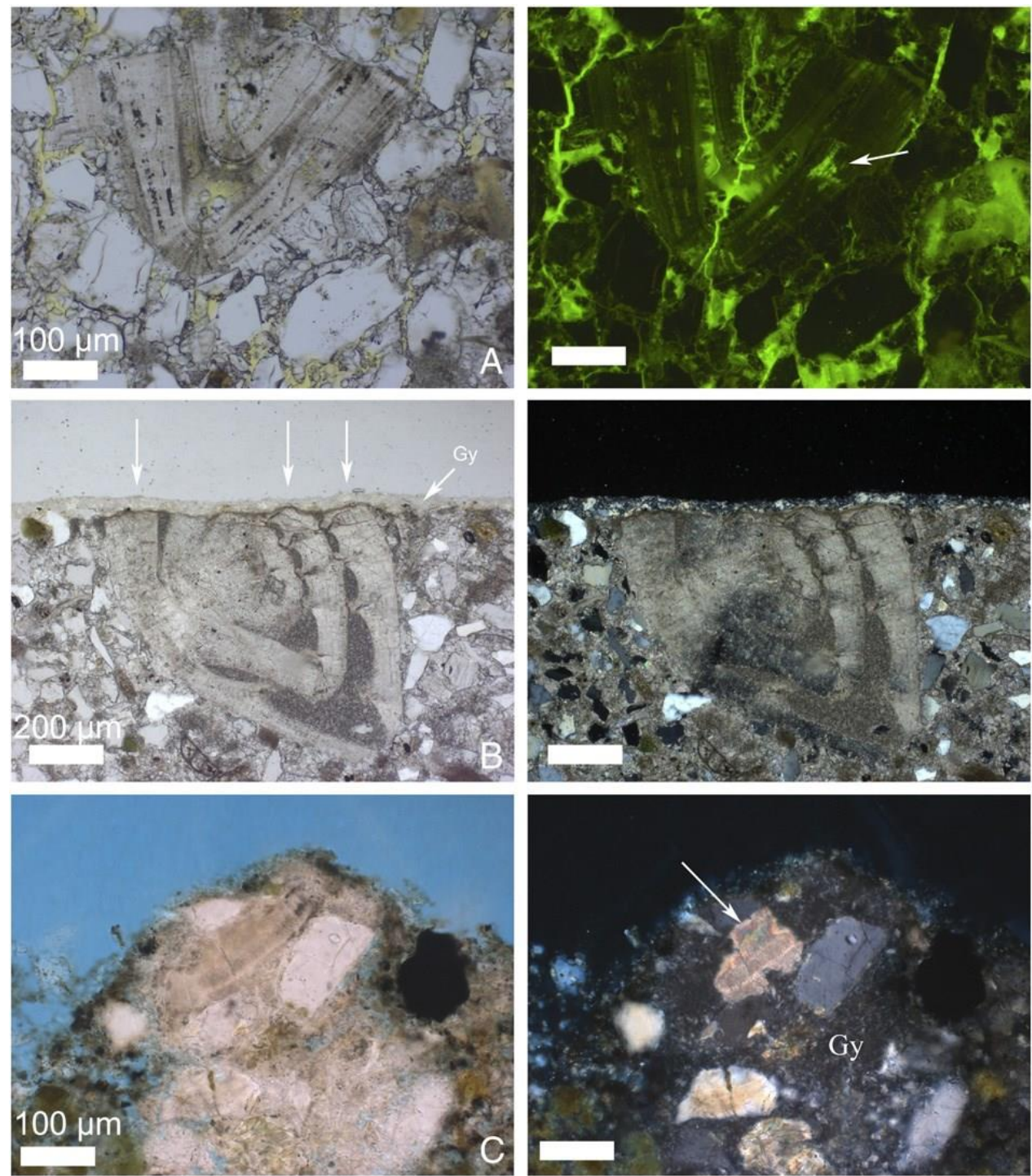

Fig. 5. Thin sections of weathered foraminifera (Nummulites variolarius) just below the gypsum crust inside the Lede stone. The top row (A) shows the dissolution of some parts of the foraminifera (arrow) and a central crack structure, colored green in an urban 
Dewanckele J., Boone, M.A., De Kock, T., De Boever, W., Brabant, L., Boone, M.N., Fronteau, G., Van Hoorebeke, L., Jacobs, P., Cnudde, V. 2013. Holistic approach of pre-existing flaws on the durability of two limestones. Science of The Total Environment. 447. p.403-414. http://dx.doi.org/10.1016/j.scitotenv.2012.12.094

environment weathered sample. The middle row (B) visualizes the specific weathering pattern of a $\mathrm{N}$. variolarius just below the gypsum crust. The arrows indicate the wall structures standing in relief after laboratory induces weathering. The bottom row (C) illustrates some remains of a foraminifer (N. variolarius) (arrow) in a thick gypsum (Gy) crust. All the surrounding cement and the outer parts of the animal test are completely recrystallized (weathering in an urban environment). (For interpretation of the references to color in this figure legend, the reader is referred to the web version of this article.)

Concerning the foraminifera fragments of the subgroup Rotaliina (Nummulites) no gypsum recrystallization was found in the fragments in the center of the sample (Fig. 7). However, some modifications were found in a part located closer to the surface of the sample and thus closer towards the weathering front. An overview is given in Fig. 9 which shows the 2D reconstructed slices of the initial situation, the weathering of the fragment in an acid environment after 10 days and after 21 days respectively. As can be seen after 10 days, some outer parts of the fossil are partially dissolved (arrow), while the internal structure is still preserved. After 21 days, the degradation of the fragment is continuing, dissolving more parts in the outer layer of the animal test (arrow). By dissolving the calcium carbonate of the fossil, a more porous zone is left behind because no secondary infilling with gypsum was detected in the fossil

3.1.1.3. SEM-EDS. Because of the lack of unambiguous chemical information in the X-ray CT data, the scanned samples were used for SEM-EDS analysis. A small cylindrical core was embedded in resin and reduced by polishing to obtain a surface corresponding to the slice obtained in X-ray CT. Fig. 10 shows a SEM image and the according EDS mappings of $\mathrm{Ca}$ (white), $\mathrm{Si}$ (blue) and $\mathrm{S}$ (red). Those elements correspond with the calcite $\left(\mathrm{CaCO}_{3}\right)$ cement, the quartz $\left(\mathrm{SiO}_{2}\right)$ grains and the newly formed gypsum $\left(\mathrm{CaSO}_{4} \cdot 2 \mathrm{H}_{2} \mathrm{O}\right)$. Four different areas were scanned with EDS and as the figure shows, the gypsum crystals are concentrated on the border of the moldic pore (dissolved shell fragment) (in areas 1 and 2) and a part of an elongated foraminifer wall structure (area 4) (right upper corner). On the SEM image, also a part of a Nummulites (Num) is visible (area 3), with perforated wall structure. However, on the corresponding EDS mapping, no sulfur elements could be measured and thus no conversion into gypsum has occurred in this fossil.
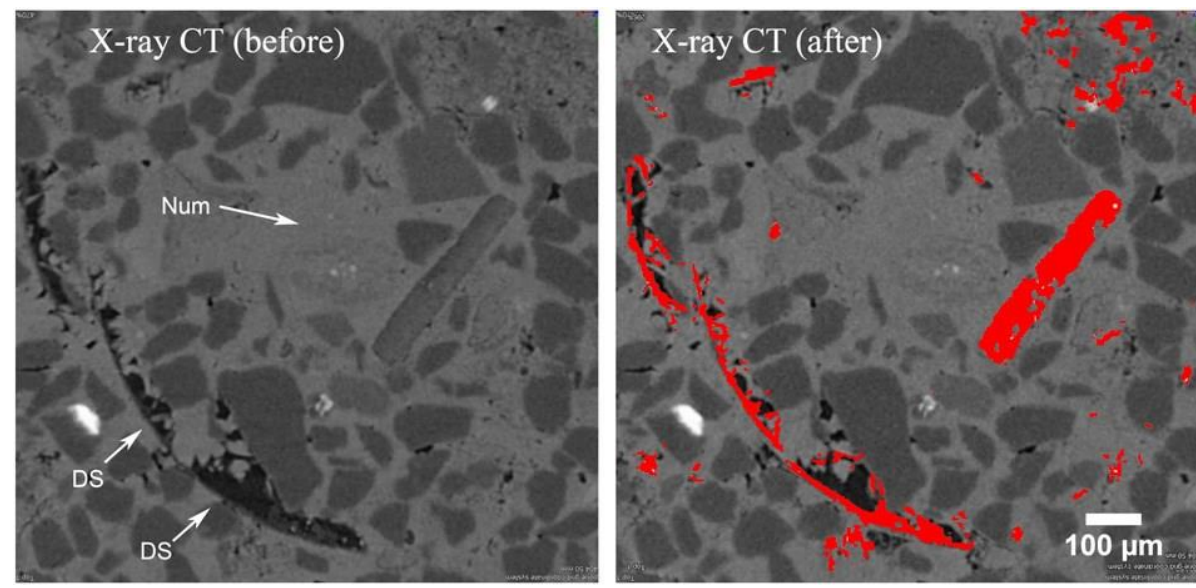

Fig. 7. 2D reconstructed X-ray CT images of a part of the Lede stone before (left) and after (right) gypsum crystallization. The red zones represent the places were gypsum and calcium carbonate were crystallized and were obtained by thresholding a differential image of a slice before and after weathering. DS; dissolved shell fragment, Num; Nummulites. (For interpretation of the references to color in this figure, the reader is referred to the web version of this article.).

\subsubsection{Noyant stone}

3.1.2.1. Petrographic microscopy. The Noyant limestone was weathered by applying a strong acid test and thin sections were realized. Afterwards thin sections were prepared of the weathered state. In case of the Noyant stone, only artificial weathered samples were used for the characterization of the recrystallizations. As can be seen in Fig. 11, a thick 
Dewanckele J., Boone, M.A., De Kock, T., De Boever, W., Brabant, L., Boone, M.N., Fronteau, G., Van Hoorebeke, L., Jacobs, P., Cnudde, V. 2013. Holistic approach of pre-existing flaws on the durability of two limestones. Science of The Total Environment. 447. p.403-414. http://dx.doi.org/10.1016/j.scitotenv.2012.12.094

weathering crust of newly formed gypsum crystals and recrystallized calcium carbonate was found. In the outer $300 \mu \mathrm{m}$, the highly macro- and nanoporous micritic matrix was completely transformed by the acid attack. As can be seen in Fig. 11, foraminifera (Miliolina) at the surface of the sample were partially attacked by the acid environment but not preferentially as can be observed in the Lede stone. The thickness of the crust of gypsum and recrystallized calcium carbonate was equally distributed over the surface of the sample. However, when O. complanatus is touching the surface, a preferential accumulation of gypsum and recrystallized calcium carbonate inside these fossil fragments could be observed. Sometimes, observations of a complete dissolution of the O. complanatus' outer part could be made.

3.1.2.2. High resolution X-ray CT. By scanning the same cylindrical sample before and after weathering, a structural comparison could be performed comparable to the one on the Lede stone. Two reconstructed slices are shown in Fig. 12, before and after weathering. In the latter case, a thick weathering crust can be seen on the surface of the sample. In addition, the micritic matrix was significantly cracked. Because of the deformation processes and displacements along the cracks, it was impossible with VGStudio ${ }^{\circledR}$ MAX to virtually replace each deteriorated part of the stone back in its original non-weathered volume. Because of the severe weathering however, no subtraction of both scans could be performed and thus the results are discussed based on the visual difference between the condition before and after weathering. Near the surface of the sample, elements (quartz grains, parts of Miliolina) were progressively integrated into the crust. No secondary porous zone behind the crust was detectible inside the volumes. Most of the foraminifera fragments (Miliolina) remained partially or completely unchanged by the acid environment as can be seen in Fig. 12. Only some outer parts of the two large foraminifera in the center of the slices were transformed. The crack structure inside the samples followed in most cases the border of the fossil fragments but also cracked the foraminifera hollow chambers from side to side.

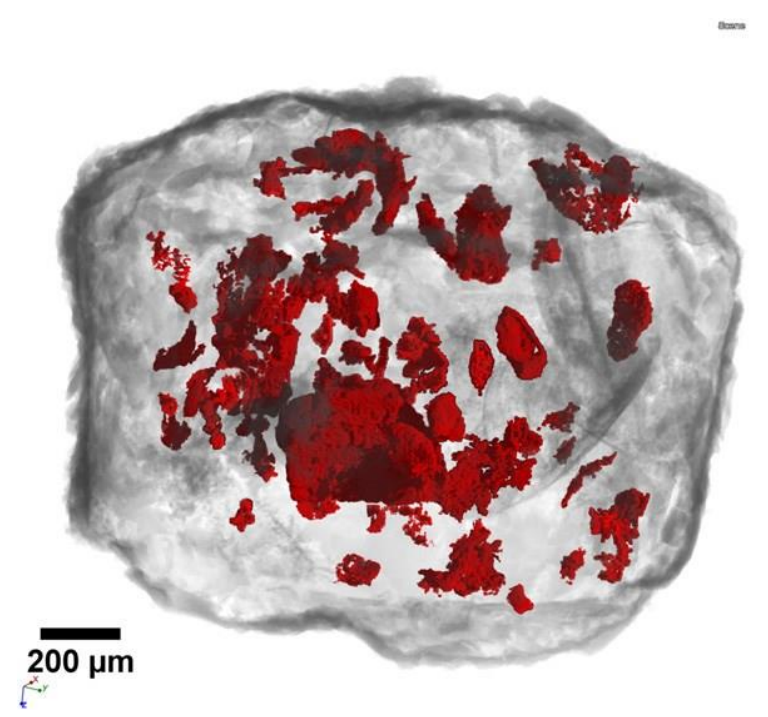

Fig. 8. 3D rendered gypsum crystallizations inside the foraminifera (Miliolina and shell fragments) inside the Lede stone. Diameter of the core is $1.6 \mathrm{~mm}$. (For interpretation of the references to color in the text with the citation of this figure, the reader is referred to the web version of this article.)

3.1.2.3. SEM-EDS. Similar to the Lede sample, a polished surface in the cylinder was scanned with HRXCT in order to afterwards perform SEM- EDS measurements. EDS mappings of Ca (white), S (red) and Si (blue) are shown in Fig. 13. On the surface of the core, a thick (100-200 $\mu \mathrm{m})$ gypsum crust is present. Quartz grains (area 4) and fossil fragments (area 2) present on the edges of the core, are fully incorporated into the newly formed gypsum layer. More to the center of the samples, some crystallization spots of gypsum are noticeable but no preferential crystallization in the Miliolina is present. Also, no gypsum was found inside and along the large crack structures.

\subsection{Freeze-thaw processes}


Dewanckele J., Boone, M.A., De Kock, T., De Boever, W., Brabant, L., Boone, M.N., Fronteau, G., Van Hoorebeke, L., Jacobs, P., Cnudde, V. 2013. Holistic approach of pre-existing flaws on the durability of two limestones. Science of The Total Environment. 447. p.403-414. http://dx.doi.org/10.1016/j.scitotenv.2012.12.094

As explained in the Methods and materials section, 6 samples of the Lede and Noyant stones were subjected to a freeze-thaw test. After the test, both series were visual inspected. Noyant limestone was totally weathered and cracked, while Lede stone was still intact. In order to observe of the severe weathering of Noyant limestone, several cores of 9 $\mathrm{mm}$ and one core of $1.6 \mathrm{~mm}$ diameter were drilled to scan with HRXCT. The freeze-thaw weathering of the Lede stone is not included in this study. On the larger cores $(9 \mathrm{~mm})$, crack structures were detected, starting from the 5th freezethaw cycle. In all of the samples, the crack structures initiate at the border of large O. complanatus fossils and follow its structure as can be seen on the 3D rendered slices, derived from HRXCT measurements, in Fig. 14. The two arrows on the figure taken after 6 cycles indicate two elongated fossil fragments. After the 7th cycle, a large crack structure initiated at the edge of one of the two fossils, while a small part of the stone had already clipped off. During the subsequent cycles, the crack structure broadened from $100 \mu \mathrm{m}$ (after 7 cycles) to around $300 \mu \mathrm{m}$ (after 10 cycles) and penetrated in to the fossils as well. During cycle 8, a second microcrack started to form (arrow) around the second fossil fragment. After 11 cycles, a significant part of the stone was removed. In order to understand the mechanisms occurring in the early stages of the freezing and thawing process (before the 5th cycle), a smaller core $(1.6 \mathrm{~mm})$ was scanned to obtain higher detail. As Fig. 15 demonstrates, the resolution of the scan increased significantly whereby the weathering of smaller individual foraminifera could be observed already from the first cycle. The brittle wall structures of the fossils became deteriorated after the first cycle while afterwards, parts were flaking off as can be seen in Fig. 15. In addition, cracks developed inside the microporous wall structure of the fossils. No cracks or other weathering phenomena were detected in the stone matrix.

\section{Discussion}

Gypsum crusts disfigure and damage limestones used as building materials. Although it is known that gypsum forms as a product resulting from a reaction of calcium carbonate and sulfur dioxide in combination with water, little research has been done on the spatial distribution of gypsum crystallization at pore scale levels and its influence of the microfacies of the limestone (Torok et al., 2007; Vergès-Belmin, 1994). The aim of this study was to obtain a time lapse visualization and characterization of specific weathering patterns due to gypsum crystallization and freeze-thaw cycles. Hereby, a coupling between thin section petrography, SEM-EDS and HRXCT was proposed. Similar weathering forms could be expected for the same bioclasts (foraminifera) in both stones when exposed to the same laboratory environment. But this study demonstrated differences in crystallization spots due to different microfacies of the stones.

In case of the Lede stone, due to dissolution, crystallization and recrystallization, not only calcitic cement but also detrital grains (glauconite and quartz) and bioclasts were gradually incorporated into the superficial weathering crust. Previous studies on the deterioration of the Lede stone by the dissolution of calcium carbonate and the formation of gypsum already revealed that the Lede stone has little resistance to air pollution. Nijs et al. (1988) demonstrated that the gypsum layer of an urban weathered Lede stone is formed in the micropores around quartz and glauconite grains and that the latter are finally fragmented by the invading crystals. The zones of dissolution around the detrital grains are also quantified and visualized in 3D (Dewanckele et al., 2012).
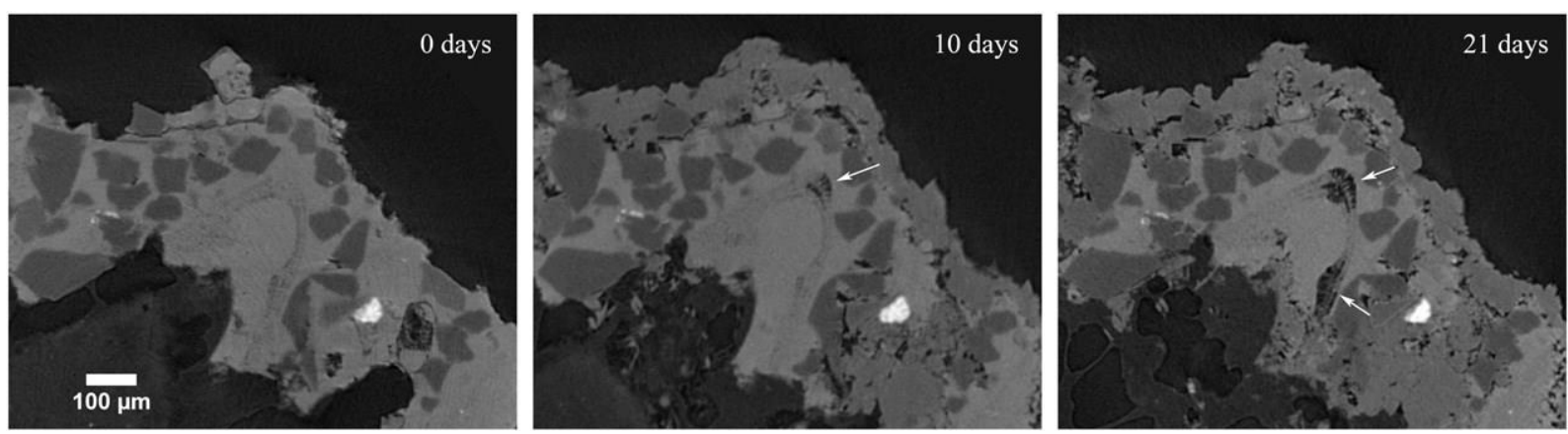

Fig. 9. 2D rendered X-ray CT slices showing the deterioration pattern of a large foraminifera (Nummulites variolarius) after 10 and 21 days of acid attack near the surface of the Lede stone. The arrow shows the dissolution zones in the fossil walls. 
Dewanckele J., Boone, M.A., De Kock, T., De Boever, W., Brabant, L., Boone, M.N., Fronteau, G., Van Hoorebeke, L., Jacobs, P., Cnudde, V. 2013. Holistic approach of pre-existing flaws on the durability of two limestones. Science of The Total Environment. 447. p.403-414. http://dx.doi.org/10.1016/j.scitotenv.2012.12.094

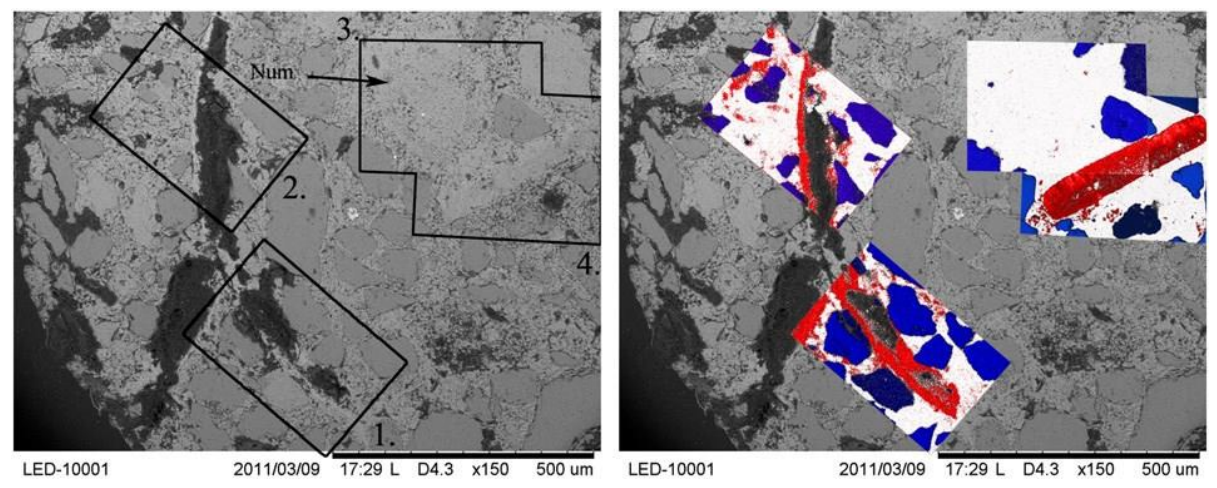

Fig. 10. SEM image and corresponding EDS mappings on a polished section of the Lede sample. Red: S; blue, Si; white: Ca. Sulfur is mainly concentrated inside the bioclasts. (For interpretation of the references to color in this figure, the reader is referred to the web version of this article.).

Although, in a natural environment several parameters (frost action, polluting particles, biological activity, ...) influence the decay of stone, regarding the weathering aspects of a gypsum crust, similar structural disintegrations can be seen. The influence of grain boundaries as primary flaws was already discussed for stones subjected to freeze-thaw cycles (Nicholson and Nicholson, 2000). In the weathered samples of the Lede stone fossil fragments such as Miliolina (Quinqueloculina) and some external parts of dissolved or micritized shell fragments were preferentially replaced by gypsum with respect to the cement. This is shown in Fig. 8 demonstrating the 3D distribution of gypsum in the Lede sample. This figure illustrates that the entire transformation into gypsum of the Miliolina fragments may occur, whereas the surrounding calcitic cement remained unaltered. The difference in pore structure and of calcite crystal sizes and thus reactive surface between the fossil fragments and the cement might explain, to some extent, this phenomenon. A high amount of microporosity inside the Miliolina walls due to the random orientations of crystallites favors dissolution and recrystallization of the original material. The microporous structure of the Miliolina fragments could be observed with fluorescence microscopy (Fig. 3) and SEM images of the porcelaneous wall show submicron, complex pore structures (Scholle and UlmerScholle, 2003). Also, the borders of moldic pores, such as dissolved shell fragments were transformed. The remains of the shell fragments were preferentially transformed. The high porous remains of the fragments (bright luminescent zones with fluorescence microscopy) were more vulnerable to transformation than the cement around as demonstrated in Fig. 6. In contrast, almost no crystallization of gypsum was found inside the N. variolarius fragments as could be observed with all techniques. Probably, the lack of abundant pore space, the large size of calcite crystals in the hyaline wall and thus the low reactive surface of the N. variolarius, compared to the surrounding porous nano and microgranular cement is a limiting factor for the recrystallization of gypsum. It seems that the radial hyaline wall structure does not favor dissolution and replacement by gypsum. However, fragments, found at the surface of the Lede stone, were partially weathered, but still were less prone to weathering than the surrounding matrix. This is observed with thin section petrography and HRXCT. Two different weathering patterns occur (1) crystallization spots inside the wall structure and (2) gradual dissolution of the outer wall structure. It could be stated that the weathering of the N. variolarius follows in some way the lamellar zones or growth structure of the fossil test. 
Dewanckele J., Boone, M.A., De Kock, T., De Boever, W., Brabant, L., Boone, M.N., Fronteau, G., Van Hoorebeke, L., Jacobs, P., Cnudde, V. 2013. Holistic approach of pre-existing flaws on the durability of two limestones. Science of The Total Environment. 447. p.403-414. http://dx.doi.org/10.1016/j.scitotenv.2012.12.094
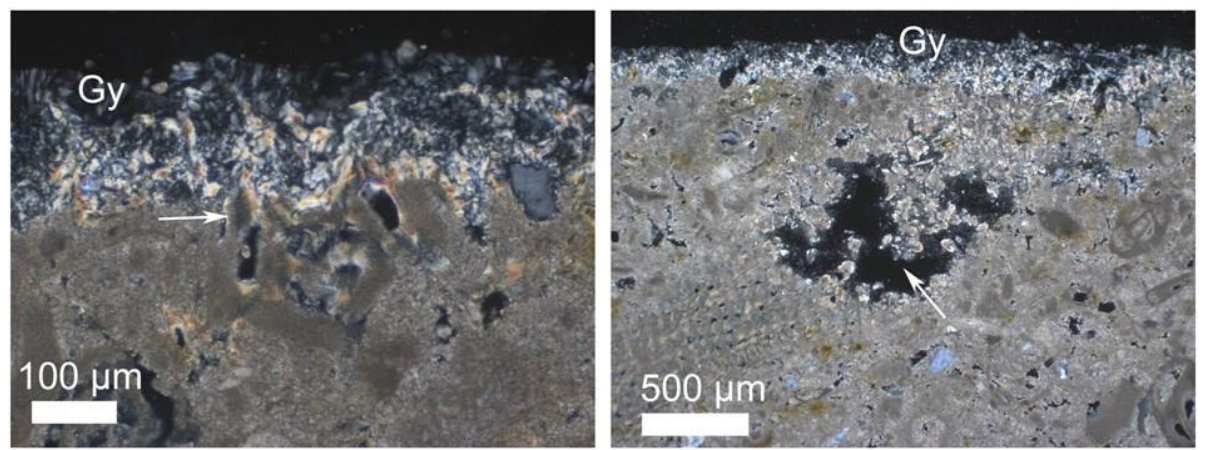

Fig. 11. Thin section under crossed polarized lights of a weathering crust on the Noyant limestone. Below the external gypsum crust (Gy), the foraminifer (Miliolina) is attacked by the sulfur but not preferential inside the wall structures. The right image shows the preferential weathering of a part of an Orbitolites complanatus, resulting in large secondary pores (arrow).

Contrarily, in the case of Noyant stone, the replacement process initiated at the surface of the sample progressed inside by dissolving the matrix of the stone instead of preferentially replacing the Miliolina fragments. This could be noticed both on the thin sections as chemically identified on the SEM-EDS images. Due to the high amount of micropores inside the micritic matrix, recrystallizations occurred preferentially in the matrix instead of inside the bioclasts. The $\mathrm{SO}_{2}$ was largely consumed by the matrix and thus only limited portions could penetrate deeper into the stone's interior to take part in the recrystallization processes inside the bioclasts. When looking to the specific total pore surface area in Table 1 , it can be seen that this is significant higher for the Noyant stone. This higher surface area may explain to some extent the high reactivity in the micritic matrix of the stone. In addition, Fig. 1 shows that the amount of micropores (smaller than $1 \mu \mathrm{m}$ ) for the Noyant stone is around 4 times higher for the Noyant stone. It might be that the thicker gypsum crust, in comparison with the Lede stone, prevented somehow the infiltration of the acid atmosphere inside the stone. Although almost no transformation could be seen in the Quinqueloculina fragments, the O. complanatus at the surface of the sample were preferential weathered with respect to the matrix (Fig. 11).
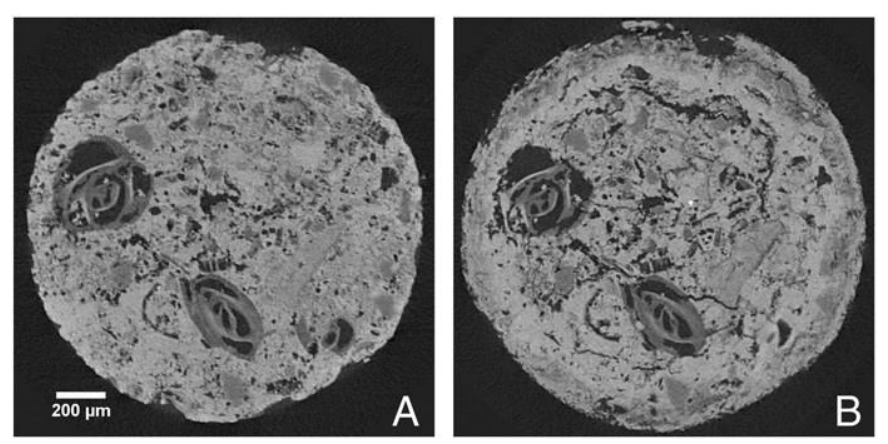

Fig. 12. Reconstructed slices of the Noyant limestone before (A) and after (B) weathering. Two large foraminifera (Miliolina) are visible in the center. After weathering; the micritic matrix and the two large foraminifera were cracked. Diameter of the sample is $1.6 \mathrm{~mm}$ and the resolution is $2.5 \mu \mathrm{m}$.

The study of progressive decay of rocks due freeze-thaw cycles has already been assessed by X-ray CT (de Argandona et al., 1999). The authors investigated the weathering pattern of a dolomitic rock with a microcrystalline texture with a medical CT scanner with a resolution of $100 \mu \mathrm{m}$ and slices of $1 \mathrm{~mm}$ tick. Microcracks were visible on the slices. However, to visualize and quantify changes that occur on pore scale

(in the order of several micrometer), HRXCT has to be used. For the Noyant stone, the O. complanatus fragments were pre-existing flaws for the cracks due to freeze-thaw cycles. The characterization of the freeze-thaw tests of the Noyant limestone showed microcracks occurring at the boundaries of those fossil fragments traversing the cylindrical cores, starting around the 5th cycle. During the subsequent cycles, the cracks propagated and widened along and inside 
Dewanckele J., Boone, M.A., De Kock, T., De Boever, W., Brabant, L., Boone, M.N., Fronteau, G., Van Hoorebeke, L., Jacobs, P., Cnudde, V. 2013. Holistic approach of pre-existing flaws on the durability of two limestones. Science of The Total Environment. 447. p.403-414. http://dx.doi.org/10.1016/j.scitotenv.2012.12.094

the fossils. This was already observed by Boone et al. (2009). Kranz (1983) suggested the initiation of microcracks at flaws and heterogeneities, like in case of the elongated fossil fragments in the Noyant stone. Furthermore, the durability and resistance of natural building stones to crack formations due to ice crystallization processes are based on both the solid body and pore space distribution. The former is mainly determined by the cement or matrix of the stone and thus the interlocking of crystals (Ruedrich et al., 2011). It can be suggested that the interlocking of crystals in the matrix is less at the boundaries of the fossil, here a quite plane surface, and thus act as zones of weakness for cracking. The identification of macrofossils and shell fragments as primary flaws has also been suggested by Nicholson and Nicholson (2000). Because the O. complanatus fossils are elongated in one direction they become preferentially cracked when traversing the sample. In this way, significant parts of the stone can deteriorate. In general, the O. complanatus fossils can be seen as a major flaw in the Noyant stone for both freeze-thaw resistance, as well as gypsum crystallization processes. However, in the primary stages of freezing and thawing (first cycles), the wall structures of some Miliolid fragments were preferentially deteriorated with respect to the matrix and no cracking was observed around the $\mathrm{O}$. complanatus fossils. This could be attributed to the lack of matrix around the Miliolid fragments, thus leading to a direct exposure of the brittle wall structures to the environment. In addition, the ratio between chamber volume and supporting wall structure also plays an important role. The large chambers and few walls in the Miliolid fossils compared to the small chambers with numerous folded walls might explain, to some extent, these early stages of deterioration. 
Dewanckele J., Boone, M.A., De Kock, T., De Boever, W., Brabant, L., Boone, M.N., Fronteau, G., Van Hoorebeke, L., Jacobs, P., Cnudde, V. 2013. Holistic approach of pre-existing flaws on the durability of two limestones. Science of The Total Environment. 447. p.403-414. http://dx.doi.org/10.1016/j.scitotenv.2012.12.094

Although weathering of natural building stones is determined by external factors (temperature, rain, pollutant gasses, etc.), weathering patterns may vary based on the microfacies of the stone (Nicholson, 2001). Mcgee and Mossotti (1992) made already a comparison between gypsum crust formation and the underlying stone structure. Limestone and marble briquette samples were both identically exposed at the same site conditions and an appreciable difference was observed in the development of the weathering crusts. The alteration crust on the porous limestone accumulated significantly more than on the marble samples. The authors allocated the difference to a dissimilar underlying pore structure, which is made out of micropores in the matrix and fossil fragments in the limestone. The marble equivalent only contained $0.3 \%$ water accessible porosity. They suspected that the adsorption of sulfate on the pore walls must be a significant factor in the sulfate-limestone reaction; due to a higher reactive surface of the limestone, a thicker gypsum crust was formed in comparison to marble briquettes. The same observations were made by Fronteau et al. (2010b).
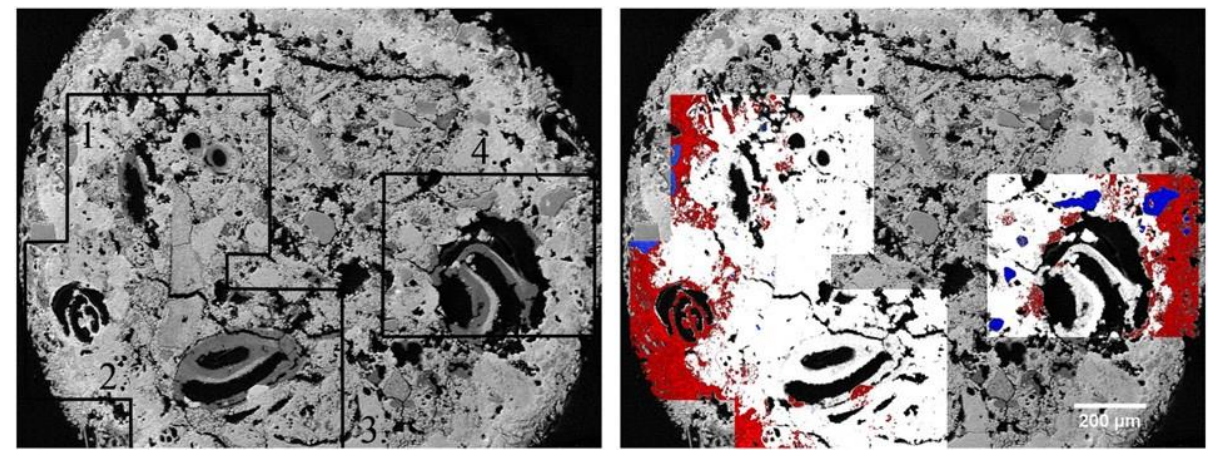

Fig. 13. SEM image and corresponding EDS mappings on an internal surface of the Noyant limestone. Red: S; blue, $\mathrm{Si}$; white: Ca. (For interpretation of the references to color in this figure, the reader is referred to the web version of this article.).

The authors investigated the development of sulfated crusts and progression of gypsum crystallizations of three different French limestones. One of the stones, the Courville limestone, is a stone similar to the Noyant stone, with a high amount of bioclasts and a dominant micro- and nanoporosity inside the matrix. In this stone, the rock fabric elements (bioclasts) were more resistant to weathering than the matrix. The influence of the microporosity in the cement on the weathering pattern is not only demonstrated in bioclastic limestones but also in oolitic counterparts. In oosparitic limestone, the gypsum crystallization spots are located in the calcitic oolites, while the oomicrite limestone shows a more complete replacement of the micritic cement (Schiavon, 1992; Fronteau et al., 2010b). The coarser interlocking calcite crystals of the sparitic cement in contrast to the microcrystalline calcite of the micrite cement lead to a different weathering pattern of the oolites inside the stone (Schiavon, 1992). The smaller crystal-size of the micrite cement offers a greater specific area for chemical attack and Schiavon (1992) provided this as an additional explanation as to why micrite is more easily attacked than larger sparite calcite crystals. However, it is important to take into account the size of the porous network and the organization of the calcite crystals in order to estimate the weathering behavior. Cenozoïc

micritic limestones, such as the Noyant stone, are soft limestones with an important microporous network and they differ from oolitic limestones with spar cement. Compared to the sparitic limestone, these microporous micritic limestones are more easily weathered by salt. They have a more important salt susceptibility (Yu and Oguchi, 2010). Recently, observation of the influence of bioclasts on the weathering of the stones in monuments has already been observed by Cultrone et al. (2008) were the selective weathering is highlighted by characteristic algal nodules in the Syracuse limestone. 
Dewanckele J., Boone, M.A., De Kock, T., De Boever, W., Brabant, L., Boone, M.N., Fronteau, G., Van Hoorebeke, L., Jacobs, P., Cnudde, V. 2013. Holistic approach of pre-existing flaws on the durability of two limestones. Science of The Total Environment. 447. p.403-414. http://dx.doi.org/10.1016/j.scitotenv.2012.12.094

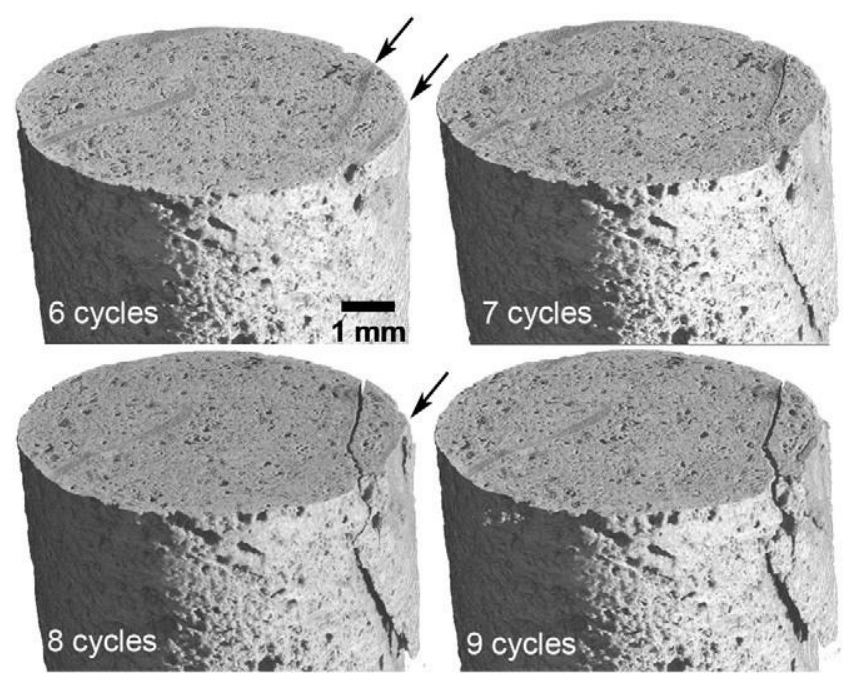

Fig. 14. 3D rendered volumes of the Noyant limestone from the 6th towards the 9th freeze-thaw cycle. Crack structures initiate at the large Orbitolites complanatus fragment. Diameter of the sample is $9 \mathrm{~mm}$.

This study showed that, by using different techniques a 3D structural and chemical analysis of both the gypsum crust formation of the Noyant stone and the Lede stone could be obtained before and after weathering. Although HRXCT has some important advantages as compared to SEM-EDS and thin section microscopy, it needs to be used critically. An obvious limitation of the application of HRXCT imaging is that structures below the resolution of the scan cannot be detected. In order to increase the resolution and thus the detail of the image smaller sample sizes are necessary. Although there is a constant improvement in the design in X-ray CT systems and reconstruction software, small sample sizes remain unavoidable. Recently, Cnudde et al. (2011) demonstrated that higher resolutions $(0.7 \mu \mathrm{m})$ are achievable on a laboratory based CT scanner (Masschaele et al., 2007).

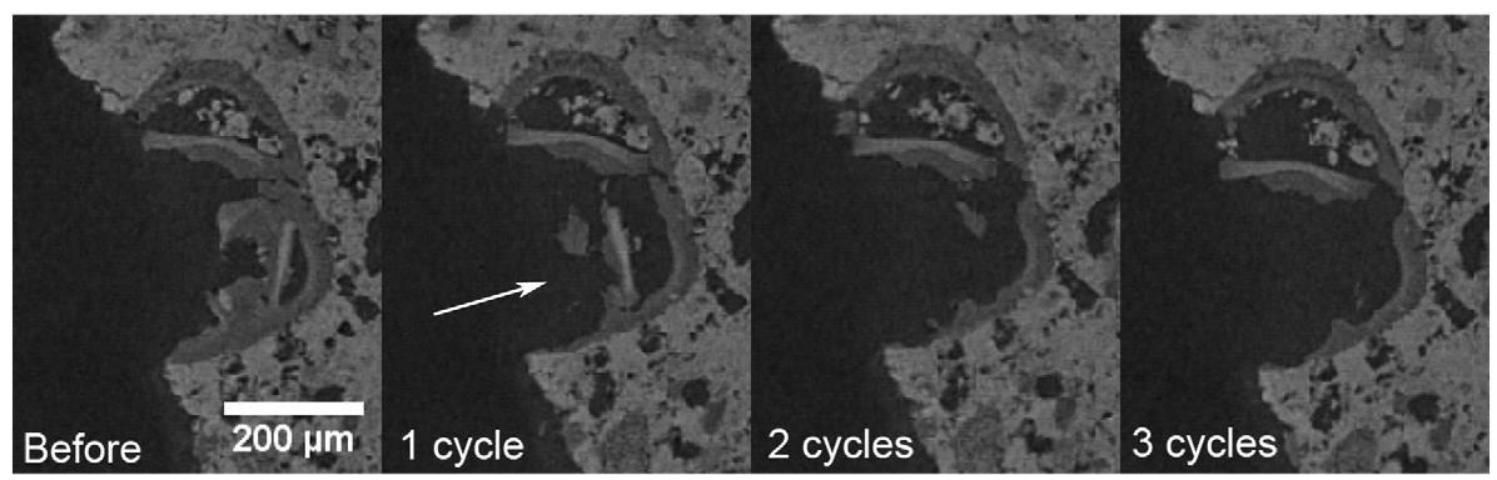

Fig. 15. Reconstructed slices of the disintegration of a foraminifer (Miliolina) due to frost action. From left to right; before the weathering test, after 1, 2 and 3 cycles respectively.

A second limitation is the lack of chemical information of the CT images. Although different minerals have different attenuation coefficients, based on their density and atomic number, in some cases the resulting gray values are too similar to separate the minerals from one another. In this study, the gray values of gypsum and calcium carbonate are almost the same; in order to differentiate the two minerals a comparison with the initial, non-weathered state is thus required. In case of the Noyant stone, no registration was possible due to the severe cracking of the sample. However, because of the non-destructive character of the technique, the same sample could be used for the EDS-mappings to obtain chemical information. Also, HRXCT is frequently used in combination with X-ray fluorescence mappings (XRF) (Boone et al., 2011; Cnudde et al., 2009; Dewanckele et al., 2009) and when combined with synchrotron-based X-ray fluorescence even a full 3D mapping is possible (De Samber et al., 2008). Sometimes, a differential image can also provide indirect chemical information. When comparing Figs. 7 and 10, the similarity of information obtained by thresholding a differential image and SEM-EDS, can be observed. However, based on a differential image, no differentiation can be 
Dewanckele J., Boone, M.A., De Kock, T., De Boever, W., Brabant, L., Boone, M.N., Fronteau, G., Van Hoorebeke, L., Jacobs, P., Cnudde, V. 2013. Holistic approach of pre-existing flaws on the durability of two limestones. Science of The Total Environment. 447. p.403-414. http://dx.doi.org/10.1016/j.scitotenv.2012.12.094

made between newly formed gypsum or recrystallized calcium carbonate. On the other hand, a full 3D image of structural changes can be obtained. The technique of a differential volume is frequently used in the field of geosciences and in most cases locations of water or other liquids in stones can be visualized (Ketcham and Iturrino, 2005). A drawback of thin section microscopy and SEM-EDS is the sample preparation: crucial information can be lost due to cutting and intensive polishing by removing parts of the weathering crust.

\section{Conclusion}

The understanding of changes that occur in natural building stones due to weathering is crucial in the field of restoration and conservation of our cultural heritage. In order to do so, not only information on the exact location of the deterioration but also a time-lapse, 3D structural assessment of the different weathering forms is required. By providing in a non-destructive way, high quality X-ray CT images before and after weathering, morphological changes can be revealed in three dimensions. By combining this technique with SEM-EDS and thin section microscopy, chemical and spatial information can be added. In this study, two types of limestone were presented, the Lede stone and the Noyant stone. It is notable that the mode of deterioration of these limestones due to gypsum crystallization and freezing and thawing depends significantly upon the microfacies of the stone and thus the presence of pre-existing flaws. The results of this study show that the pore size distribution and reactive surface of the cement, matrix or elements affects the location of the crystallization spots inside the stone. In the Lede stone, fossil fragments (Miliolina) weathered preferentially with respect to the microsparitic cement. Almost no transformation was found in the N. variolarius fragments. In the Noyant stone, the micritic matrix was the main cause of decay. The elongated O. complanatus fragments act as pre-existing flaws in the Noyant stone for both freeze-thaw as gypsum crystallization.

\section{Acknowledgments}

The authors would like to thank the Agency for Promotion of Innovation by Science and Technology in Flanders, Belgium (IWT) for the PhD grant of J. Dewanckele and the Special Research Fund of the Ghent University (BOF) for the grant of L. Brabant. Beltrami is acknowledged for providing the rock samples of the Noyant stone. J. Jurceka and PELCON are thanked for preparing the thin sections. We would also thank the two anonymous referees for their comments.

\section{References}

Bai Y, Thompson GE, Martinez-Ramirez S, Brueggerhoff S. Mineralogical study of salt crusts formed on historic building stones. Sci Total Environ 2003;302:247-51.

Bathurst RG. Carbonate sediments and their diagenesis. Developments in sedimentoloy. Amsterdam, London, New York: Elsevier; 1971.

Boone M, De Kock T, Dewanckele J, Cnudde V, Van Loo D, Van de Casteele E, et al. Four-dimensional monitoring of freeze-thaw cycles in limestone with X-ray computed microtomography (micro-CT). Proceedings 12th Euroseminar on microscopy applied on natural building stones; 2009. p. 20-8.

Boone M, Dewanckele J, Boone M, Cnudde V, Silversmit G, Van Ranst E, et al. Three-dimensional phase separation and identification in granite. Geosphere 2011;7:79-86.

Bost M, Dubied JSG. Natural and artificial micro-cracking in limestone: a model of response to freezing-thawing. Preservation of natural stone and rock weathering; 2007. p. 17-23. Brabant L, Vlassenbroeck J, De Witte Y, Cnudde V, Boone MN, Dewanckele J, et al. Three-dimensional analysis of high-resolution X-ray computed tomography data with Morpho+. Microsc Microanal 2011;17:252-63.

Bugani S, Camaiti M, Morselli L, Van de Casteele, Janssens K. Investigating morphological changes in treated vs. untreated stone building materials by X-ray micro-CT. Anal Bioanal Chem 2008;391:1343-50.

Camuffo D. Physical-weathering of stones. Sci Total Environ 1995;167:1-14.

Charola AE, Puhringer J, Steiger M. Gypsum: a review of its role in the deterioration of building materials. Environ Geol 2007;52:207-20. 
Dewanckele J., Boone, M.A., De Kock, T., De Boever, W., Brabant, L., Boone, M.N., Fronteau, G., Van Hoorebeke, L., Jacobs, P., Cnudde, V. 2013. Holistic approach of pre-existing flaws on the durability of two limestones. Science of The Total Environment. 447. p.403-414. http://dx.doi.org/10.1016/j.scitotenv.2012.12.094

Cnudde V, Cnudde JP, Dupuis C, Jacobs PJS. X-ray micro-CT used for the localization of water repellents and consolidants inside natural building stones. Mater Charact 2004;53:259-71.

Cnudde V, Masschaele B, Dierick M, Vlassenbroeck J, Van Hoorebeke L, Jacobs P. Recent progress in X-ray CT as a geosciences tool. Appl Geochem 2006;21:826-32.

Cnudde V, Silversmit G, Boone M, Dewanckele J, De Samber B, Schoonjans T, et al. Multi-disciplinary characterisation of a sandstone surface crust. Sci Total Environ 2009;407:5417-27.

Cnudde V, Boone M, Dewanckele J, Dierick M, Van Hoorebeke L, Jacobs P. 3D characterization of sandstone by means of X-ray computed tomography. Geosphere 2011;7:54-61.

Cultrone G, Russo LG, Calabrò M, Urosevic Pezzino A. Influence of pore system characteristics on limestone vulnerability: a laboratory study. Environ Geol 2008;54:1271-81.

de Argandona VGR, Rey AR, Celorio C, del Rio LMS, Calleja L, Llavona J. Characterization by computed X-ray tomography of the evolution of the pore structure of a dolomite rock during freeze-thaw cyclic tests. Phys Chem Earth Solid Earth Geod 1999;24:633-7.

De Graef B, Cnudde V, Dick J, De Belie N, Jacobs P, Verstraete W. A sensitivity study for the visualisation of bacterial weathering of concrete and stone with computerised X-ray microtomography. Sci Total Environ 2005;341:17383.

De Kock T. De ledesteen en zijn hedendaagse vervangstenen: een vergelijkende studie. Master thesis scription 2009; $205 \mathrm{pp}$.

De Muynck W, Leuridan S, Van Loo D, Verbeken K, Cnudde V, De Belie N, et al. Influence of pore structure on the effectiveness of a biogenic carbonate surface treatment for limestone conservation. Appl Environ Microbiol 2011;77:6808-20.

De Samber B, Silversmit G, Evens R, De Schamphelaere K, Janssen C, Masschaele B, et al. Three-dimensional elemental imaging by means of synchrotron radiation micro-XRF: developments and applications in environmental chemistry. Anal Bioanal Chem 2008;390:267-71.

Dewanckele J, Cnudde V, Boone M, Van Loo D, De Witte Y, Pieters K, et al. Integration of X-ray micro tomography and fluorescence for applications on natural building stones. 9th International Conference on X-ray Microscopy; 2009. p. 186.

Dewanckele J, De Kock T, Boone MA, Cnudde V, Brabant L, Boone MN, et al. 4D imaging and quantification of pore structure modifications inside natural building stones by means of high resolution X-ray CT. Sci Total Environ 2012;416:436-48.

Dierick M, Masschaele B, Van Hoorebeke L. Octopus, a fast and user-friendly tomographic reconstruction package developed in LabView (R). Meas Sci Technol 2004;15:1366-70.

Dolske DA. Deposition of atmospheric pollutants to monuments, statues, and buildings. Sci Total Environ 1995;167:15-31.

Duliu OG. Computer axial tomography in geosciences: an overview. Earth Sci Rev 1999;48:265-81.

Dusar M, Rn Dreesen, De Naeyer A. Natuursteen in Vlaanderen, versteenverleden. 1st ed. Mechelen: Wolters Kluwer België NV; 2009.

Fobe B. Voorkomen, samenstelling en gebruik van de Balegemse steen. Bull Soc Geol Belg 1990;99-2:167-70.

Fronteau G, Moreau C, Thomachot-Schneider C, Barbin V. Variability of some Lutetian building stones from the Paris Basin, from characterisation to conservation. Eng Geol 2010a;115:58-166.

Fronteau G, Schneider-Thomachot C, Chopin E, Barbin V, Mouze D, Pascal A. Black-crust growth and interaction with underlying limestone microfacies. Geological Society, London, Special Publications, 333. 2010b. p. 25-34.

Kapsalas P, Maravelaki-Kalaitzaki P, Zervakis M, Delegou ET, Moropoulou A. Optical inspection for quantification of decay on stone surfaces. NDT and E Int 2007;40:2-11.

Ketcham RA, Carlson WD. Acquisition, optimization and interpretation of X-ray computed tomographic imagery: applications to the geosciences. Comput Geosci 2001;27: 381-400. 
Dewanckele J., Boone, M.A., De Kock, T., De Boever, W., Brabant, L., Boone, M.N., Fronteau, G., Van Hoorebeke, L., Jacobs, P., Cnudde, V. 2013. Holistic approach of pre-existing flaws on the durability of two limestones. Science of The Total Environment. 447. p.403-414. http://dx.doi.org/10.1016/j.scitotenv.2012.12.094

Ketcham RA, Iturrino GJ. Nondestructive high-resolution visualization and measurement of anisotropic effective porosity in complex lithologies using high-resolution X-ray computed tomography. J Hydrol 2005;302:92-106.

Kranz RL. Microcracks in rocks — a review. Tectonophysics 1983;100:449-80.

Leysen LA, Roekens EJ, Vangrieken RE, Degeyter G. Characterization of the weathering crust of various historical buildings in Belgium. Sci Total Environ 1990;90:117-47.

Lopez-Arce P, Varas-Muriel MJ, Fernandez-Revuelta B, de Buergo MA, Fort R, Perez-Soba C. Artificial weathering of Spanish granites subjected to salt crystallization tests: surface roughness quantification. Catena 2010;83:170-85.

Maravelaki-Kalaitzaki P, Biscontin G. Origin, characteristics and morphology of weathering crusts on Istria stone in Venice. Atmos Environ 1999;33:1699-709.

Masschaele BC, Cnudde V, Dierick M, Jacobs P, Van Hoorebeke L, Vlassenbroeck J. UGCT: new X-ray radiography and tomography facility. Nucl Instrum Methods Phys Res, Sect A 2007;580:266-9.

Matovic V, Eric S, Kremenovic A, Colomban P, Sreckovic-Batocanin D, Matovic N. The origin of syngenite in black crusts on the limestone monument King's Gate (Belgrade Fortress, Serbia) — the role of agriculture fertiliser. J Cult Herit 2012;13:175-86.

Mcgee ES, Mossotti VG. Gypsum accumulation on carbonate stone. Atmos Environ Part B 1992;26:249-53.

Montana G, Randazzo L, Oddo IA, Valenza M. The growth of "black crusts" on calcareous building stones in Palermo (Sicily): a first appraisal of anthropogenic and natural sulphur sources. Environ Geol 2008;56:367-80.

NBN B17-001. Belgium standard, Vorstbestendigheid: waterimpregnatie-vorstdooicyclussen-gebruikscriteria; 1999.

NBN EN 12371. Natural stone test methods — determination of frost resistance (2010); 2010.

NBN EN 13919. Natural stone test methods-determination of resistance to ageing by $\mathrm{SO}_{2}$ action in the presence of humidity; 2003.

Nicholson DT. Pore properties as indicators of breakdown mechanisms in experimentally weathered limestones. Earth Surf Processes Landforms 2001;26:819-38.

Nicholson DT, Nicholson FH. Physical deterioration of sedimentary rocks subjected to experimental freeze-thaw weathering. Earth Surf Processes Landforms 2000;25: 1295-307.

Nijs R, De Geyter G, Fobe B. Behaviour of the historic Balegem stone and its substitute, the Gobertange stone in Flemish monuments. The engineering geology of ancient works, monuments and historical sites: preservation and protection, 2. Proceedings International Symposium (Greek National Group of IAEG); 1988. p. 843-8.

Ortiz P, Vazquez MA, Ortiz R, Martin JM, Ctvrtnickova T, Mateo MP, et al. Investigation of environmental pollution effects on stone monuments in the case of Santa Maria La Blanca, Seville (Spain). Appl Phys A: Mater Sci Process 2010;100:965-73.

Rozenbaum O. 3-D characterization of weathered building limestones by high resolution synchrotron X-ray microtomography. Sci Total Environ 2011;409:1959-66.

Ruedrich J, Kirchner D, Siegesmund S. Physical weathering of building stones induced by freeze-thaw action: a laboratory long-term study. Environ Earth Sci 2011;63:1573-86.

Sanjurjo JS, Alves CAS, Romani JRV, Mosquera DF. Origin of gypsum-rich coatings on historic buildings. Water Air Soil Pollut 2009;204:53-68.

Sanjurjo JS, Romani JRV, Alves C. Deposition of particles on gypsum-rich coatings of historic buildings in urban and rural environments. Construct Build Mater 2011;25:813-22.

Schiavon N. BSEM study of decay mechanisms in urban oolitic limestones. Eur Cult Herit 1992;6:35-46.

Scholle PA, Ulmer-Scholle DS. A color guide to the petrography of carbonate rocks. AAPG Mem 2003;77. [Tulsa].

Siegesmund S, Torok A, Hupers A, Muller C, Klemm W. Mineralogical, geochemical and microfabric evidences of gypsum crusts: a case study from Budapest. Environ Geol 2007;52:369-81.

Thomachot C, Jeannette D. Effects of iron black varnish on petrophysical properties of building sandstone. Environ Geol 2004;47:119-31.

Thomachot-Schneider C, Gommeaux M, Fronteau G. Modifications of the porous network of sandstone accompanying the formation of black varnish. Environ Geol 2008;56:571-82. 
Dewanckele J., Boone, M.A., De Kock, T., De Boever, W., Brabant, L., Boone, M.N., Fronteau, G., Van Hoorebeke, L., Jacobs, P., Cnudde, V. 2013. Holistic approach of pre-existing flaws on the durability of two limestones. Science of The Total Environment. 447. p.403-414. http://dx.doi.org/10.1016/j.scitotenv.2012.12.094

Torok A, Rozgonyi N. Morphology and mineralogy of weathering crusts on highly porous oolitic limestones, a case study from Budapest. Environ Geol 2004;46:333-49.

Torok A, Siegesmund S, Muller C, Hupers A, Hoppert M, Weiss T. Differences in texture, physical properties and microbiology of weathering crust and host rock: a case study of the porous limestone of Budapest (Hungary), 271. Building stone decay: from diagnosis to conservation; 2007. p. 261-76.

Torok A, Licha T, Simon K, Siegesmund S. Urban and rural limestone weathering; the contribution of dust to black crust formation. Environmental Earth Sciences 2011;63:675-93.

Vergès-Belmin V. Pseudomorphism of gypsum after calcite, a new textural feature accounting for the marble sulfation mechanism. Atmos Environ 1994;28:295-304.

Vlassenbroeck J, Dierick M, Masschaele B, Cnudde V, Hoorebeke L, Jacobs P. Software tools for quantification of X-ray microtomography. Nucl Instrum Methods Phys Res, Sect A 2007a;580:442-5.

Vlassenbroeck J, Masschaele BC, Dierick M, Cnudde V, De Witte Y, Pieters K, et al. Recent developments in the field of X-ray nano- and micro-CT at the Centre for X-ray Tomography of the Ghent University. Microsc Microanal 2007b;13: 184-5.

Yu S, Oguchi CT. Is sodium sulphate invariably effective in destroying any type of rock? Geological Society, London, Special Publications, 333. 2010. p. 43-58.

Zappia G, Sabbioni C, Riontino C, Gobbi G, Favoni O. Exposure tests of building materials in urban atmosphere. Sci Total Environ 1998;224:235-44. 